\title{
Cyclobutadienyl dications as intermediates in the rapid degenerate rearrangements of 4-halo-1,2,3,4-tetrasubstituted cyclobutenyl cations
}

\author{
Citation for published version (APA): \\ Hout-Lodder, van der, A. E., Haan, de, J. W., \& Buck, H. M. (1974). Cyclobutadienyl dications as intermediates \\ in the rapid degenerate rearrangements of 4-halo-1,2,3,4-tetrasubstituted cyclobutenyl cations. Recueil des \\ Travaux Chimiques des Pays-Bas, 93(6), 156-157. https://doi.org/10.1002/recl.19740930604
}

DOI:

10.1002/recl. 19740930604

Document status and date:

Published: 01/01/1974

\section{Document Version:}

Publisher's PDF, also known as Version of Record (includes final page, issue and volume numbers)

\section{Please check the document version of this publication:}

- A submitted manuscript is the version of the article upon submission and before peer-review. There can be important differences between the submitted version and the official published version of record. People interested in the research are advised to contact the author for the final version of the publication, or visit the $\mathrm{DOI}$ to the publisher's website.

- The final author version and the galley proof are versions of the publication after peer review.

- The final published version features the final layout of the paper including the volume, issue and page numbers.

Link to publication

\footnotetext{
General rights

- You may freely distribute the URL identifying the publication in the public portal. follow below link for the End User Agreement:

www.tue.nl/taverne

Take down policy

If you believe that this document breaches copyright please contact us at:

openaccess@tue.nl

providing details and we will investigate your claim.
}

Copyright and moral rights for the publications made accessible in the public portal are retained by the authors and/or other copyright owners and it is a condition of accessing publications that users recognise and abide by the legal requirements associated with these rights.

- Users may download and print one copy of any publication from the public portal for the purpose of private study or research.

- You may not further distribute the material or use it for any profit-making activity or commercial gain

If the publication is distributed under the terms of Article 25fa of the Dutch Copyright Act, indicated by the "Taverne" license above, please 
the results of the electron density on the phosphorus atom $\left(e_{\mathrm{p}}\right)$, the adjacent carbon atom $\left(e_{\mathrm{C}}\right)$ and the net charge of the odd-ligand $\left(q_{\mathrm{X}}\right)$ are summarized. With respect to $e_{\mathrm{C}}$ we note that of the compounds which are reactive in the Wittig reaction, 2 has the lowest $e_{\mathrm{C}}$ value. The next lower value of 1.470 occurs in 3 , which is unreactive and has the same $e_{\mathrm{P}}$ value as 2 . Concerning the $e_{\mathrm{p}}$ values we notice that the largest one belongs to the (unknown) compound 4. At the same time this compound shows a smaller $e_{C}$ value than the "critical" value of 1.470 . Therefore we must conclude that 4 will not react in the Wittig reaction.

Table I Parameters used in the semi-empirical calculations.

\begin{tabular}{|c|c|c|c|}
\hline orbital & $\gamma_{\mathrm{ii}}(\mathrm{eV})$ & $\alpha_{\text {core }}(\mathrm{eV})$ & $\beta_{\mathrm{c}-\mathrm{c}}(\mathrm{eV})$ \\
\hline $\mathbf{C}_{2 \mathrm{p}}$ & 11.13 & -11.16 & -2.32 \\
$\mathbf{P}_{3 \mathrm{~d}}$ & 6.3 & -2.86 & \\
\hline
\end{tabular}

Furthermore, Table II also shows that the percentage of dipolar structure $\left(\sim\right.$ net odd-ligand charge $q_{\mathrm{X}}$ ) cannot be conclusive for reactivity in the Wittig reaction, since 5 has
Table II Calculated electron densities and comparison with reactivities.

\begin{tabular}{|c|c|c|c|c|}
\hline compound & $e_{\mathrm{P}}$ & $e_{\mathrm{C}}$ & $q_{\mathrm{X}}$ & $\begin{array}{c}\text { reactivity } \\
\text { in the } \\
\text { Wittig reaction }\end{array}$ \\
\hline 1 & 0.389 & 1.626 & - & yes \\
2 & 0.255 & 1.486 & -0.809 & yes \\
3 & 0.257 & 1.470 & -0.800 & no \\
4 & 0.484 & 1.418 & -0.276 & $?$ \\
5 & 0.179 & 1.278 & -0.900 & no \\
\hline
\end{tabular}

the largest net odd-ligand charge and is still unreactive. The fact that the $e_{\mathrm{p}}$ value is so much higher in 4 can be understood in terms of aromaticity: 4 has 4 electrons, making it anti-aromatic. This compound will therefore try to reduce the number of electrons in the ring system by donating extra electron density to the phosphorus atom. This phenomenon is in contrast with 5 which has 6 electrons and therefore tries to preserve the electrons in the ring. This is in excellent agreement with the calculated value of 5.9 electrons in the ring.

\title{
Cyclobutadienyl dications as intermediates in the rapid degenerate rearrangements of 4-halo-1,2,3,4-tetrasubstituted cyclobutenyl cations
}

\author{
A. E. van der Hout-Lodder, J. W. de Haan and H. M. Buck \\ Dep. of Organic Chemistry, Eindhoven University of Technology, The Netherlands \\ (Received March 4th, 1974)
}

\begin{abstract}
Based on ${ }^{13} \mathrm{C}$ NMR chemical shifts at variable temperatures it is suggested that cyclobutadienyl dications form essential intermediates in the rapid equilibration of 4-halo-1,2,3,4-tetrasubstituted cyclobutenyl cations.
\end{abstract}

Recently ${ }^{1}$, we published the ${ }^{13} \mathrm{C}$ NMR spectrum of the 1,2,3,4-tetraphenylcyclobutenyl cation (I). Comparison of the sum of all relevant chemical shifts of I with the reported values of a compound, supposed to be the 1,2,3,4-tetraphenylcyclobutadienyl dication (II) indicated similar amounts of positive charges.

On repeating Olah's original experiment (dissolution of 1,2dibromo-1,2,3,4-tetraphenylcyclobutene in $\mathrm{SO}_{2} \mathrm{ClF} / \mathrm{SbF}_{5}$ at $-60^{\circ}$ ), we obtained a much better resolved CMR spectrum. The chemical shift of the carbons of the four-membered ring was found at $19.6 \mathrm{ppm}^{*}$. All phenyl rings were found to be equivalent and showed signals at 44.95, 55.28, 60.88 and $72.41 \mathrm{ppm}$. These peaks were assigned to the para, ortho, meta and $\alpha$-carbons, respectively.

Warming this solution to $-20^{\circ}$ resulted in a down-field shift of the four-membered ring signals by about $9 \mathrm{ppm}$. This effect was no artifact as was shown by the unchanged positions of the aromatic signals as well as the lock substance with respect to the carrier frequency.

From these results, it appears that at $-60^{\circ}$ as well as at $-20^{\circ}$, we have observed rapidly equilibrating degenerate monobromo cations. At more elevated temperatures ionic contributions (IV) become more important with respect to covalent structures (III). (See scheme).

* All shifts were measured relative to $\mathrm{C}_{2} \mathrm{~F}_{4} \mathrm{Br}_{2}$ and subsequently transferred to the $\mathrm{CS}_{2}$ scale.

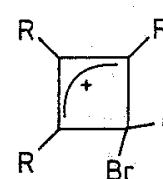

III
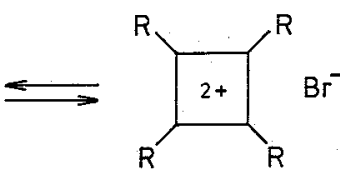

IV

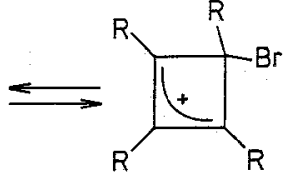

III

\section{Scheme 1}

Analogous conclusions have been arrived at quite recently by Henrichs and Peterson ${ }^{2}$ in a study of CMR chemical shifts in substituted tetramethylene halonium ions**.

PPP calculations on the tetraphenylcyclobutadiene dication using a symmetrical propeller model in which the phenyl rings are turned out of the plane of the four-membered ring by $45^{\circ}$, yield about 0.3 unit of positive charge on each of the cyclobutadiene carbons. Also taking into account the intrinsic substituent effect of the phenyl ring ${ }^{3}$, one would

** Detailed application of their equation 1 did not seem to be appropriate in the present case because of the relatively large uncertainties in the substituent effects, exerted by bromine.

1 A. E. van der Hout-Lodder, J. W. de Haan, L. J. M. van de Ven and H.M. Buck, Rec. Trav. Chim. 92, 1040 (1973).

2 P. M. Henrichs and P. E. Peterson, J. Am. Chem. Soc. 95, 7449 (1973).

3 J. Mason, J. Chem. Soc. (A), 1038 (1971). 
predict the four-membered ring carbons at $-5 \mathrm{ppm}$ relative to $\mathrm{CS}_{2}$.

In this respect it might be of interest to reconsider the reported tetramethylcyclobutadiene dication, obtained by warming a solution of 4-chloro-1,2,3,4-tetramethylcyclo- butenyl cation. The experimental shift at $-75^{\circ}$ proved to be -14.4 ppm compared with a predicted value of about -35 ppm. In our opinion, the possibility of interconversion between mono- and di-cations cannot be excluded for this case.

\title{
Photochemical additions of $o$-quinones and benzil to conjugated alkenynes
}

\author{
R. J. C. Koster, D. G. Streefkerk, Mrs. J. Oudshoorn-van Veen and H. J. T. Bos
}

Laboratory of Organic Chemistry, State Iniversity Utrecht, Croesestraat 79, The Netherlands (Received January 10th, 1974)

\begin{abstract}
Phenanthraquinone (PQ) and tetrachloro-o-benzoquinone were added photochemically to the double bond of various substituted alkenynes (1), yielding dihydrodioxin derivatives $(2,5)$; in some cases oxetane derivatives (4) were isolated too. Generally the photochemical addition occurred non-stereospecifically. Reversible additions of PQ to the double bond were established. Thermal additions of tetrachloro-o-benzoquinone occurred with retention of configuration. The photochemical addition of benzil to conjugated alkenynes and to alkenes, however, led to oxetanes (6) only.
\end{abstract}

\section{Results}

9,10-Phenanthraquinone. Irradiation of a solution of 9,10phenanthraquinone (PQ) with excess of an alkenyne (1) in benzene in all cases gave addition to the double bond, generally affording a cis-trans mixture of 2-(1-alkynyl)-2,3dihydro-1,4-dioxin derivatives (2) (see Table I). Addition of PQ to 1-ethynylcyclohexene ( $\mathrm{H}$ and $c i s \mathrm{C} \equiv \mathrm{CH})$ even afforded the trans adduct (3) as the sole product:<smiles>[R]C#CC([R])=C([R])C</smiles>

(1)
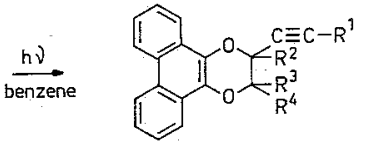

(2, cis + trans $)$
Table I Some results of the photoaddition reactions of $P Q^{\mathrm{a}}$.

\begin{tabular}{|l|c|c|c|c|l|}
\hline \multicolumn{1}{|c|}{ Alkenyne 1 } & $\begin{array}{c}\text { Ratio } \\
\text { reactants }\end{array}$ & Adduct & $\begin{array}{c}\text { Yield } \\
\%\end{array}$ & m.p. $\left({ }^{\circ} \mathrm{C}^{\mathrm{b}}\right.$ & Product remarks \\
\hline $\mathrm{R}^{1}=\mathrm{R}^{2}=\mathrm{R}^{3}=\mathrm{R}^{4}=\mathrm{H}$ & 15 & $\mathbf{2}$ & 21 & $108-109$ & \\
\hline $\begin{array}{l}\mathrm{R}^{1}=\mathrm{R}^{4}=\mathrm{H} \\
\mathrm{R}^{2}+\mathrm{R}^{3}=\left(\mathrm{CH}_{2}\right)_{4}\end{array}$ & 2 & $2 \equiv 3$ & 13 & $211-212$ & cis/trans $<0.05$ \\
\hline $\begin{array}{l}\mathrm{R}^{1}=\mathrm{R}^{3}=\mathrm{R}^{4}=\mathrm{H} \\
\mathrm{R}^{2}=\mathrm{CH}_{3}\end{array}$ & 11 & 2 & 50 & $175-176$ & \\
\hline $\begin{array}{l}\mathrm{R}^{1}=\mathrm{R}^{2}=\mathrm{R}^{4}=\mathrm{H} \\
\mathrm{R}^{3}=\mathrm{CH}_{3} \\
(\text { cis })\end{array}$ & 40 & 2 & 57 & $155-156$ & cis/trans $=4^{\mathrm{b}}$ \\
\hline $\begin{array}{l}\mathrm{R}^{1}=\mathrm{R}^{2}=\mathrm{R}^{4}=\mathrm{H} \\
\mathrm{R}^{3}=\mathrm{OCH} \\
(\text { cis })\end{array}$ & 16 & 2 & 50 & $124-130$ & cis/trans $=1$ \\
\hline $\begin{array}{l}\mathrm{R}^{1}=\mathrm{R}^{2}=\mathrm{R}^{4}=\mathrm{H} \\
\mathrm{R}^{3}=\mathrm{OCH}_{3} \\
(\text { cis })\end{array}$ & 16 & 4 & 13 & $137-139$ & cis/trans $=5$ \\
\hline
\end{tabular}

ather adducts 2 were obtained from the reaction of PQ with: 1-octen-3-yne: m.p. 209$210^{\circ} \mathrm{C}$, yield $11 \%$; 2-hexen-4-yne (cis + trans): $117-118^{\circ} \mathrm{C}-21 \%$; 3-hexen-1-yne (cis + trans): oil - $31 \%$ and 4-methyl-3-hexen-1-yne (cis + trans): oil $-44 \%$

$4 \%$ of the recovered enyne was isomerized.

Melting points given are uncorrected.
${ }^{1} \mathrm{H}$-NMR, IR, UV and MS spectral data were in conformity with the structures assigned ${ }^{1-6}$ (see Table II).

Photolyses of PQ with 1-methoxy-1-buten-3-yne and 3penten-1-yne gave also oxetanes (4) in 13 and $8 \%$ yield respectively, as judged from spectral data ${ }^{6,7}$ (see Table II).

In general considerable amounts of chromatographically highly polar material was found, presumably $\mathrm{RH}$ adducts $^{9-11}$, and other hydrogen-abstraction reaction products; these were not investigated. As has been found for some activated alkynes ${ }^{12-14}$ no addition of $P Q$ to the triple bond was observed. Recovery of non-reacted cis- or trans-1(methylthio)-3-hexen-1-yne and of cis-penten-1-yne in the reaction with $\mathrm{PQ}$ showed some cis-trans isomerization of the alkenyne.<smiles>C#CC12CCCC1Oc1ccccc1O2</smiles>

(3)

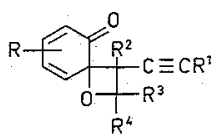

(4)<smiles>[R]C1Oc2c(Cl)c(Cl)c(Cl)c(Cl)c2OC1C#[W]</smiles>

(5.cis + trans $)$
Tetrachloro-o-benzoquinone. Irradiation of some alkenynes with tetrachloro-o-benzoquinone gave analogous dihydro1,4-dioxin adducts (5) (see Tables III and IV).

${ }^{1}$ H. J. T. Bos, C. Slagt and J.S. M. Boleij, Recl. Trav. Chim. 89, 1170 (1970).

2 S. Farid, Dissertation Univ. Göttingen, 1967.

3 D. Bryce-Smith and A. Gilbert, Chem. Comm, 1968, 1701.

4 G. Pfundt and S. Farid, Tetrahedron 22, 2237 (1966).

5 G. Pfundt, Dissertation Univ. Göttingen, 1962.

${ }^{6}$ C. H. Krauch, S. Farid and G.O. Schenck, Chem. Ber. 98, 3102 (1965).

7 S. Farid, D. Hess and C. H. Krauch, Chem. Ber. 100, 3266 (1967).

8 J. M. Bruce, Quart. Rev. 21, 405 (1967).

9 S. Farid and K. H. Scholz, Chem. Comm. 1968, 412.

${ }_{10}$ M. B. Rubin, Fortschr. Chem. Forsch. 13, 251 (1969).

11 K. Maruyama, H. Shindo and T. Maruyama, Bull. Chem. Soc. Japan 44, 585 (1971).

12 H. J. T. Bos, H. Polman and P. F. E. van Montfort, J.C.S. Chem. Comm. 1973, 188.

13 D. Bryce-Smith and A. Gilbert, Chem. Comm. 1968, 1702.

14 U. Weiss, H. Ziffer and J.M. Edwards, Austr. J. Chem. 24, 657 (1971). 